\title{
Formation of a Study Program in the Context of Conformity with the ESG (on the Material of the Analysis of Study Programs in Ukraine)
}

\author{
Andrii Butenko, Ganna Denyskina and Olena Yeremenko *(D)
}

check for updates

Citation: Butenko, A.; Denyskina, G.; Yeremenko, O. Formation of a Study Program in the Context of Conformity with the ESG (on the Material of the Analysis of Study Programs in Ukraine). Educ. Sci. 2021, 11, 670 . https://doi.org/10.3390/educsci 11110670

Academic Editors: Serhii Stepenko, Nataliia Stukalo and Asnate Kažoka

Received: 31 August 2021

Accepted: 5 October 2021

Published: 21 October 2021

Publisher's Note: MDPI stays neutral with regard to jurisdictional claims in published maps and institutional affiliations.

Copyright: (c) 2021 by the authors. Licensee MDPI, Basel, Switzerland. This article is an open access article distributed under the terms and conditions of the Creative Commons Attribution (CC BY) license (https:// creativecommons.org/licenses/by/ $4.0 /)$.
National Agency for Higher Education Quality Assurance, 01001 Kyiv, Ukraine; abutenko@naqa.gov.ua (A.B.); gdenyskina@naqa.gov.ua (G.D.)

* Correspondence: oyeremenko@naqa.gov.ua

\begin{abstract}
The article discusses the issues of forming a study program in the context of the process' compliance with the recommendations provided by Standards and Guidelines for Quality Assurance in the European Higher Education Area (ESG), which are relevant for Ukrainian higher education. The study achieved its goal: the main prerequisites for the formation of the study program (SP) were analyzed, its structural and semantic parameters were determined, and a step-by-step model of concluding a quality study program in accordance with the ESG guidelines was suggested. The search for the materials on which the study was based was conducted using the following databases: scientometric (Scopus, Web of Science), the information system (online platform) of the National Agency for Quality Assurance in Higher Education (NAQA), and the "Legislation of Ukraine" database. Quantitative methods included an online questionnaire, qualitative methods included system analysis, and other comparative method were used. Due to the contradictions between the interpretations of the concepts at the level of legislation and internal regulations, a definition of the "formation of the study program" concept is suggested. The components of the SP formation process, the resources required for the formation of the quality SP, and an analysis of positive and negative practices from the NAQA accreditation procedure experience, based on which the optimal model of the SP as a dynamic system based on ESG guidelines was developed, which has a functional character and is based on theoretical generalization of the latest approaches and real cases of Ukrainian HEIs, were discussed.
\end{abstract}

Keywords: study program; stakeholder engagement; external and internal quality assurance; accreditation processes; model of study program; stages of formation of study program; quality of study program; National Agency for Higher Education Quality Assurance

\section{Introduction}

\subsection{Prerequisites and History of the Issue: Scientific and Legislative Aspects}

The formation, development, and improvement of global education systems takes place in different ways, but the common principles are (1) the interest of the applicants and employers in the quality of education, (2) the autonomy of institutions, and (3) the involvement of stakeholders in the quality of education assurance. It is significant that today, researchers from different continents state both the necessity and inevitability of changes in the field of higher education and a certain inertia in this field [1,2].

However, significant changes in other areas of human life: social, economic, media, etc., lead to a constant review of the role and place of higher education in social processes, and hence to other approaches to ensuring its quality, which, in turn, require technology and improvement mechanisms, including the qualitative formation of the study program (SP). A milestone for the development of common approaches to higher education reforms in Europe was the development of Standards and Guidelines for Quality Assurance in the European Higher Education Area (ESG), the key objective of which is to contribute to the 
common understanding of quality assurance for learning and teaching across borders and among all stakeholders [3] (p. 6). In particular, this document contains guidelines for the formation of the SP (standard 1.2) [3] (pp. 11-12).

The qualitative organization of the study program contains the maximum involvement of all stakeholders, both external and internal ones: employers, the higher education institution (HEI), each of the teachers and departments (laboratories, clinics, centers, etc.) that will be involved in the implementation of the SP, and an established system of communication between those responsible for the preparation of the SP. Given the above, our article suggests an approach to the study program creation, which involves the consideration of this process as a system: an explanation of the necessary steps, components, and parameters of its formation.

Understanding quality education essence as the social unity and consolidation objective of national educational systems in the context of radical changes in the Ukrainian educational sphere is at the epicenter of each higher education branch representative's scientific interests. This set of problems requires consideration not only in a purely pedagogical or scientific aspect, but also requires consideration of its social, ideological, and managerial component.

The first attempts to comprehend the latest trends in the study programs appeared in Ukraine before the regulation of the transition of the higher education system to European requirements in the law "On Higher Education" (2014). The article by I. Nesterenko "Designing study programs in the context of the functioning of the Polish qualifications framework" (2013) [4] analyzed that in accordance with the reform of approaches to study programs in Polish universities, the method of designing a new curriculum consists of five stages: conceptual, planning and defining requirements, design, implementation, testing, and evaluation. The author emphasizes the current practice in Poland of involving all stakeholders in each stage, without which it is impossible to not only develop a clear description of learning outcomes but also to predict further implementation stages of the SP.

After 2014, scientific and methodological studies have mainly outlined general approaches to the implementation of educational reforms that would bring Ukraine closer to the European educational area. Thus, in 2015, a team of authors [5] conducted an informational analytical review for the development of the Ukrainian higher education quality assurance system. This review was prepared to facilitate the process of establishing the National Agency for Quality Assurance in Higher Education of Ukraine, establishing its effective activities and forming a new culture of quality improvement in the national area of higher education in Ukraine on the basis of objectivity, transparency, trust and subsidiarity, partnership, and collegiality. A collection of articles, biographical materials, speeches, reviews, and essays, The Battlefront of Civilizations: Education in Ukraine, designed to inform about events in higher education in Ukraine from 2008 to 2015, was compiled and published by Serhiy Kvit [6].

The analysis of the leading Ukrainian and foreign experience in assessing the quality of higher education in European integration was prepared in 2019 and was based on the results of the second stage of research from "Analysis of the leading domestic and foreign experience in assessing the quality of higher education in the context of European integration (mechanisms for assessing the quality of higher education in European integration)", which was conducted by a team of scientists from the Institute of Higher Education of Ukraine [7]. The researchers identified practical approaches to implementing mechanisms for assessing the quality of higher education. The paper comprehends domestic and foreign experience and conducted a systematic classification of the mechanisms used for assessing the quality of higher education in the context of European integration and globalization. The criteria and indicators for creating mechanisms for assessing the quality of higher education are summarized. The principles of effective policy and strategy for building a system of ensuring and improving the quality of higher education and the transforma- 
tion of higher education management in the context of forming a leadership culture of competitive quality of higher education in Ukraine are substantiated.

Scientific and methodological generalization upon the issues of content and certain procedures for the formation of study programs is reflected in the work of well-known educational experts, the work of scientists from the Institute of Higher Education, in the results of international projects, etc. Yu. Rashkevych thoroughly systematizes the requirements for the construction of SP, starting, in fact, from the time of the introduction of the very concept of the study program, and in particular, emphasizes the need to comply with the standard and the general regulatory framework. In this regard, his well-known monograph, The Bologna Process and the New Paradigm of Higher Education, is his most significant work [8]. The methodological recommendations for the "development of study programs" refer to the construction of study programs through the approaches of studentcentered learning [9]. "Modern approaches to the construction of study programs" [10] are mainly focused on identifying and showing the results of the educational process.

Certain methodological achievements in this direction were observed in the first years of implementation of the law "On Higher Education" (2014), when Ukrainian teachers considered the creation of study programs in both scientific and methodological publications [11,12] It is significant that despite the authors' appeal to the relevance of the European paradigm of quality assurance in higher education and compliance with its individual provisions, it is those provisions of the ESG that relate to the formation of the SP, and they are not used in these publications. In the article "Study program as a tool to ensure the quality of training future professionals in higher education institutions", Olga Naboka conducts a general analysis of the main approaches to the formation of the SP [13]. In the investigation of O. Ishchenko "Basic approaches to the development of study programs" [14], the main development stages of the study program are given, and the main formal parameters of its formation are determined.

Current issues upon the quality assurance of the study programs and aspects of evaluating their functioning are reflected in the publication of S. Kvit "Higher Education in Ukraine in the Time of Independence: Between Brownian Motion and Revolutionary Reforms" [15].

The work of A. Butenko and O. Yeremenko is devoted to the preparation of the study program for accreditation in terms of institutional cooperation as well as the delineation of the legal status, the development of the professional and demographic portrait of the study program guarantor, and its role in quality assurance processes at the study program formation stage [16-18].

Recently, we have also seen the emergence of publications about the role of employers in shaping the study program. Researchers not only analyze the typology of stakeholders [19], but also emphasize the significant changes in the strategy resulting from their involvement in all stages of the educational activities, which took place in 2020-2021 in connection with the orientation of Ukrainian higher education to the standards of the European educational area [20].

It should be emphasized that the definition of "study program formation" is mostly found in Eastern Europe, while the works of scholars from Western European prefer the term "Curriculum Design". Given the need to update approaches to the development of study programs, the article by E. Brenner and J. Niehs "Curricula Development based on Learning Outcomes-An Austrian Case" [21] focuses on the development of SP in terms of learning outcomes.

Note that European quality assurance systems in universities have taken the appropriate path to the formation and evaluation of study programs in the early 21st century, and it is during this period that the maximum publishing activity related to the relevant issues occurs. Content published in this domain typically refers to the experience of ensuring the quality of higher education in specific HEIs in individual countries. Thus, Stefan Cronholm's article "Nine Principles for Designing a Study Program" is interesting not only because it highlights the principles themselves: Vision; Traceability; Progression and Inte- 
gration; Manning the development project and anchoring decisions; Pedagogy; Mandatory vs. free choice of courses; Implementation; and Evaluation and Marketing, but also that the SP is suggested to be designed according to their further evaluation according to the criteria of the Swedish National Agency for Higher Education [22]. Many publications are applied, as they study construction patterns of study programs in specific fields of knowledge and specialties, such as Amparo Hurtado Albir's article "Competence-based Curriculum Design for Training Translators, The Interpreter and Translator Trainer", which shows a balanced approach to the system development and the components of the SP for the training of translators [23].

In fact, the analyzed works show that the issue of forming a quality study program in the context of ESG compliance was not given due attention.

\subsection{Relevance, Purpose of the Study and Its Implementation}

The adaptation of Ukrainian higher education to the standards of education adopted in the single European educational area has been going on for more than a year, but the lack of harmonized approaches and practices to implement the recommendations and criteria set out in ESG 2015 has led to some formalism. The lack of a unified approach in the practical application of these principles and recommendations has led to a literal implementation of the law, without a significant understanding of the value and content that is behind such an approach. For example, the transformation of specializations for training in educational institutions into study programs mainly took place without changing the compilation process, without taking into account the needs of the students, employers, and other stakeholders as well as sectoral and regional needs, without a proper internal quality assurance system, including analysis tasks and the content of the study program with the involvement of specialists.

From 2018 until the full functioning of the National Agency for Quality Assurance in Higher Education, study program accreditation was conducted by the Ministry of Education and Science of Ukraine using the parameters of licensing conditions rather than requirements for quality assurance due to the lack of proper regulations. Most free educational institutions reacted to the essence of the phenomenon of "study program" quite formally. In practice, there was either a renaming of specializations as being part of the specialties in the study programs or the identification of the study programs with the specialty itself, while the essence of training has not changed. The amount of theoretical and methodological knowledge of the participants in regard to the educational process concerning study programs and the specifics of improving their parameters did not meet the requirements of legislation or European practice.

In 2019, the full-fledged accreditation of the study programs began, which revealed that a significant number of study programs, which are trained by Ukrainian higher education institutions, quality criteria for assessing SP, controlled by the Regulation on Accreditation of Study Programs (2019), only achieved partial compliance [24].

According to the results of the accreditation examinations of the study programs, a significant number of them had problems with inconsistencies in terms of the content of various parts of the study program, the formal implementation of the structural requirements, and the superficial description of the elements without taking into account real market requirements, industry features, and current legislation. This situation was confirmed by the following statistical data: in the period from 01.09.2019 to 31.12.2020, out of a total of 1400 SPs submitted for examination, $332(24 \%)$ received conditional accreditation for 1 year, and 33 were denied accreditation (2\%) [25].

The reason for such shortcomings, according to the authors of the article, is the lack of clear organization of the study program, in particular, the lack of the real coordination of its elements with different groups of stakeholders and the proper awareness of the real tasks of the project team.

Normative acts, explanations, and recommendations of the central authorities of Ukraine define the concept of the study program, define its purpose and tasks, and give 
recommendations for its structure and design. In particular: the Law of Ukraine "On Higher Education" (paragraph 17 of the first part of Article 1) [26]; (Order of the Ministry of Education and Science of Ukraine of 01.02.2021 №128 “On Approval of Requirements for Interdisciplinary Educational (Scientific) Programs") [27]; MES advisory letters 2017 №1/9-239 "Sample study program (recommendations of the Ministry of Education and Science of Ukraine)" [28]; a letter dated 05.06.2018 №1/9-377 "Regarding the provision of explanations regarding study programs" [29]; and a letter dated 09.07.2018 №1/9-434 "Regarding recommendations for educational and methodological support") [30]. At the same time, none of these documents provide clear answers on how to effectively design and implement a study program.

Therefore, the purpose of this research is to analyze the prerequisites for the formation, to determine the structural and semantic parameters, and to offer a model for concluding a quality study program in accordance with the guidelines of the ESG.

Achieving the goal requires solving the following tasks:

- Summarizing the main scientific and methodological achievements and the national and local regulatory framework for the formation of SPs;

- Determining the preconditions for the formation of a quality study program in the paradigm of new approaches to higher education in Ukraine;

- Clarifying the conceptual apparatus related to the formation of the study program;

- Finding out the potential impact of ESG standards on the formation of a quality study program;

- Defining the role and place of stakeholders in the process of forming a quality study program;

- Offering a model of study program formation with the outline of its stages correlated with ESG standards and Developing a set of measures aimed at forming a study program in accordance with the suggested model.

The lack of scientific, practical, and methodological developments of this nature has led to the need to describe the formation of a quality study program in the context of ESG compliance and to determine the relevance of this study and solutions for the following research objectives (research questions):

To characterize the scientific, methodological, and recommendatory works of Ukrainian researchers related to the initiation and conclusion of study programs in terms of educational reforms and their approximation to the requirements of the European educational area;

To single out an array of documents regulating the issues of higher education quality assurance in the design and approval of study programs and to identify problems that are not regulated by it in the Ukrainian legislation and normative base of higher education institutions;

To systematize the regularities of implementation of new approaches to higher education in Ukraine, which were introduced as a result of the laws "On Higher Education" (2014) and "On Education" (2017) and that are related to ESG 2015;

To structure the concepts and definitions related to the formation of study programs in Ukrainian universities and to outline the problems related to their definition;

To substantiate the effectiveness of the application of ESG guidelines in the SP design by providing examples of best practices;

To demonstrate how each provision of the 1.2 ESG standard determines the stages of a quality study program formation process;

To trace the need to involve stakeholders in the process of forming a quality study program;

To determine the necessary stages for the formation of the study program; the SP;

To generalize the institutional parameters of determining the ability of HEI to initiate

To emphasize the role of the guarantor and the project team in the formation of the study program; 
To provide all of the necessary actions, procedures, and technologies in the system of measures aimed at the formation of a quality study program;

To outline the prospects for the implementation of the developed model.

\section{Materials and Methods}

The theoretical basis for the formation of an SP according to the guidelines of the ESG is the harmonization of different methodological approaches in the educational organization process, and the main problem considers the methodological training of the guarantor and the working group for the formation of the SP.

The methodology of forming a study program according to ESG standards can be interpreted as covering the basic provisions, forms, methods, and principles of the educational process in higher education and the organization of effective practices in developing the training structure and content to ensure the most effective pedagogical activities.

The methodological substantiation of the qualitative study program formation covers:

(1) Theoretical understanding of the ESG 2015 guidelines in the context of educational reforms in Ukraine;

(2) The practice of organizing the SP formation process;

(3) The substantiation of this process (standardization, goal-setting, structuring, introduction of restrictions that regulate the theory and practice of the SP formation, etc.).

The organizational and methodological principles of the SP formation in accordance with the ESG guidelines are the following components:

- Conceptual-involves the definition of basic provisions and awareness of the feasibility of opening and forming an SP at all institutional management levels; the substantiation of the structural-functional model of SP construction; the availability, clarity and measurability of goals, the motivation of participants in the educational process, and decision-making efficiency;

- Normative-legal-definition of subjects and objects that are in the focus of the emerging SP, their legal status, and powers;

- Technological-introduction of an SP; in particular, the development of the internal control algorithm of an SP number (avoidance of the duplication of existing, a lack of demand from both applicants and future employers, etc.);

- Scientific-methodical-development of SP formation methods and organizational and scientific-methodical support of SP formation by the guarantor;

- Axiological-constant monitoring and evaluation of processes and procedures for providing quality education according to the formed SPs, which instead should have a humanistic orientation aiming to create the most favorable conditions for development and to cultivate respect for personality and mutual trust between the participants of the educational process without using the evaluation results as an element of coercion.

Achieving the goals and solving the problems of the study involve the use of such methods.

\subsection{Source Search Strategy and Compliance Criteria}

A systematic search of published literature was conducted using the following databases: Scopus, Web of Science, and the information system (online platform) of the National Agency for Quality Assurance in Higher Education. Keywords used: "study program", "design of study program", "quality of higher education", and "ESG". Interim and final results of the study program process accreditation, conclusions of sectoral expert councils, and reports of expert groups on the quality of Ukrainian study programs, which were used as illustrative material to the provisions of this article, were taken from the public resource public.naqa.gov.ua and the office information system naqa.gov.ua of the National Agency for Quality Assurance in Higher Education of Ukraine. The searches and processing of publications were conducted in the period from October 2020 to July 2021. Studies were included in the systematic review if they met the following criteria: (1) written in Ukrainian 
or English; (2) published between 2000 and 2021; and (3) concerned problems regarding the formation and implementation of an SP (study program). Information and analytical reviews and methodological and advisory materials were included in this study, as they important to understand the state of higher education in Ukraine.

To establish the dependence of the influence of the internal quality systems of HEI on study program formation, the method of generalization was used, which included: (1) a preliminary statement of the task, which involved the study of the evolution and trends of the Ukrainian higher education system; (2) identifying the possibility of clarifying the role of individual indicators at the study program formation stage; (3) finding the ideas, solutions, and principles necessary for the optimal formation of the study program in view of the ESG guidelines; and (4) a comprehensive analysis and evaluation of SP design measures and a determination of prospects for their implementation.

A comparative method was used to establish the contradiction between the interpretations of concepts and to compare the disadvantages and advantages as well as to search and identify similarities and differences in the process of forming an SP.

The system analysis method allowed us:

- To find out the components of the process of SP formation, the weight of each stage of its preparation (in particular, the need to balance the formal and substantive components, and the impact of economic, social, political processes, ideas, and interests of different stakeholder groups);

- To pay attention to the resources needed to form a quality SP on the basis of the revealed internal connections and dependences between the SP elements to offer the optimum SP model as the dynamic system constructed taking into account ESG instructions;

- To establish links between its main components to ensure its effective functioning in the future, as the methodology of SP formation is a complex mechanism of additions and changes and a regulator of constant stakeholder interaction in terms of the quality of the training system in higher education.

\subsection{The Process of Data Selecting and Synthesis}

The use of the quantitative method was due to the need to obtain up-to-date information through online questionnaires and was based on a survey of 576 respondentsguarantors of study programs in all regions of Ukraine, who provided data on their experiences in the study programs in Ukrainian higher education. The survey of the guarantors, which was developed and conducted by the authors of the article, consisted of 24 questions. All issues were discussed by the authors of the article. The questionnaire contained 3 open-ended questions, 9 questions with suggested answer options (including 6 multiple-choice questions), and 12 closed-ended questions ("yes" or "no"). All of the question types gave the opportunity for the participant to offer their own answer through the option "other" [31]. The survey was conducted in the period from 23 November 2020 to 15 January 2021. The answers of the guarantors of the study programs, which concern the formation of the study program, starting from considering its introduction, were analyzed.

The focus group was identified by research questions, and questionnaires were sent to the guarantors of the SPs. The survey questions were based on the self-assessment reports of HEIs according to the regulation "On Accreditation" (2019) and were not subject to additional calibration due to the close connection with the external measurement procedures used to determine the quality of education. The survey was anonymous, so the participants agreed to provide their answers without specifying their identities; the answers are impersonal; and their personal data are not used, and therefore, the use of the questionnaire did not need to be approved by the ethics committee.

The results of the survey were interpreted using a descriptive method to confirm the hypothesis and to conclude the model; therefore, it did not require special quantitative approaches for processing. 


\section{Results}

During the research, a significant amount of information on the accreditation of the study programs of Ukrainian HEIs was analyzed. The materials of the accreditation examinations revealed a certain pattern - the formation of the highest quality study programs in the different HEIs were developed in accordance with and effectively applied the internal rules of design and approval for all of the necessary documents for the implementation of the SP.

The authors summarized the information for the cases from 2019, a decision on which was made by NAQA (Table 1).

Table 1. Quantitative distribution of decisions (not on cases).

\begin{tabular}{lllll}
\hline & Bachelor's Degree & Master's Degree & Doctor of Philosophy & Together \\
\hline Exemplary & 5 & 8 & 46 & 59 \\
\hline Accreditation & 685 & 398 & 465 & 1548 \\
\hline Conditional (postponed) & 231 & 102 & 44 & 377 \\
\hline Accreditation refusal & 20 & 11 & 4 & 35 \\
\hline $\begin{array}{l}\text { Together based on the } \\
\text { education level }\end{array}$ & 941 & 519 & 559 & 2019 \\
\hline
\end{tabular}

In particular, we wanted to pay attention to the following examples (according to Table 2). During the accreditation of the study program "Philosophy" for the first (bachelor's) level of higher education at Borys Grinchenko Kyiv University, experts and members of the expert council branch noted the approach of the HEI, according to which the design of SPs is part of the process used to form a unified corporate culture based on clearly defined common values and guidelines for their implementation in practice in "Manifesto of Leadership as Service" and the Code of Corporate Culture of the HEI. Additionally, the strengths of both this study program in particular and the HEI in general, according to criterion 8 , which assesses the internal quality assurance of the study program, include: "the existence of clear and regulated procedures for reviewing the SP; internal quality assurance of the educational process on the basis of involvement in the relevant procedures of monitoring and decision-making of participants in the educational process upon different levels; clarity and transparency of internal standards for education inner quality assurance; involvement of employers in assessing the quality of student training (management of internships from practice bases; participation in the work of examination commissions; co-management of qualifying works; participation in the employers' council in the format of analysis of current "cases" and focus groups" [32].

Table 2. The ratio of model accreditations to the number of accredited SPs in terms of individual HEIs.

\begin{tabular}{lllll}
\hline HEI & $\begin{array}{l}\text { Bachelor's } \\
\text { Degree }\end{array}$ & $\begin{array}{l}\text { Master's } \\
\text { Degree }\end{array}$ & $\begin{array}{l}\text { Doctor of } \\
\text { Philosophy }\end{array}$ & $\begin{array}{l}\text { Exemplary SPs That Have } \\
\text { Received Accreditation }\end{array}$ \\
\hline Borys Grinchenko Kyiv University & 2 & - & 2 & $4 / 19$ \\
\hline $\begin{array}{l}\text { Simon Kuznets Kharkiv National } \\
\text { University of Economics }\end{array}$ & - & - & 1 & $1 / 6$ \\
\hline Sumy State University & 1 & 1 & 4 & $6 / 16$ \\
\hline Lviv Polytechnic National University & - & - & 4 & $4 / 38$ \\
\hline Vasyl' Stus Donetsk National University & - & - & 1 & $1 / 6$ \\
\hline
\end{tabular}

The analysis of the regulations on the competitive selection of scientific and pedagogical workers showed that the transparency of competitive selection procedures provided during the formation of the study program and their standardization [33] ensures the required level of professionalism of scientific and pedagogical workers at the time of when the study program is implemented. Thus, the competitive selection of staff provided by 
the SP "Cybersecurity" for the first (bachelor's) higher education level at Simon Kuznets Kharkiv National Economic University clearly defined and took the requirements and professional activities of the teachers of the SP into account. These requirements include the following parameters: scientific degree (depending on the position), academic title (depending on the position), experience with scientific and pedagogical work in accordance with the profile of the study program in higher education institutions, and availability of scientific-methodical and scientific works [34]. That is, they demonstrated the ability to provide quality applicant training in accordance with the acquired level of higher education, professional, and scientific qualifications, etc. To ensure transparency and publicity, the announcement of the competition to fill vacant research and teaching staff positions was posted on the university website [35].

The key figure in the composition of scientific and pedagogical leaders is the guarantor of the study program, but so far, no normative act approves its status, powers, etc., except for the Glossary, which is of a recommendatory nature [36]. The organization, formation, and quality control of the study program depends on the guarantor. The article by A. Butenko and O. Yeremenko "The role of the guarantor in the formation of the study program" highlights some developments of Ukrainian HEIs, in particular those of Sumy State University, Simon Kuznets Kharkiv National University of Economics, Lviv Polytechnic National University. According to the authors, the local normative act of the Ivan Chernyakhovsky National University of Defense of Ukraine deserves special attention: the idea of the act and initiation of formation with the separation of functional possibilities of all of the involved people are detailed (Methodical recommendations for realization of study programs, 2020). Such materials can be presented as requirements for the structure of the study program and its search algorithm (Methodical instruction, 2017) and the selectivity of the organization (Organization of the educational process, 2017). Complex documents in which the further implementation of study programs with a certain mechanism of changes made to them is determined are optimal (Regulations on formation, approval and renewal, 2017) [18] (p. 47).

In order to study the activities of guarantors as key figures in the formation of the study program, their survey was conducted on certain parameters of this process, which are partially described in the publications of A. Butenko and O. Yeremenko [18]. In particular, it was found that the initiative to start SPs in Ukrainian universities mainly belonged to the academic community ( $89 \%$ of respondents), including the administration of the HEI (28.8\% of respondents), the department as the main structural unit responsible for implementing the SPs ( $31.8 \%$ of respondents), and the faculty ( $14.2 \%$ of respondents). Only $11 \%$ of the SPs were initiated solely at the initiative of the stakeholders (employers or educators).

An important component in building a quality study program is the experience analysis of the educational activities/practices of foreign universities. Thanks to the survey, we can state that in general, higher education institutions study this experience. Study program guarantors determined both which foreign study programs are worth considering in the context of the formation of their SP (75\% of respondents) and personally analyzed foreign study programs in respect to the formation of the planned SP $(73.6 \%$ of respondents). Most of the interviewed guarantors were only interested in educational components $(79.3 \%)$, which shows that the general approach in studying the experience of other SPs [18] (pp. 52-53). In view of this, it is worth noting the institutional support policy for the formation of the regulatory framework for SPs of the Vasyl Stus Donetsk National University, where the regulations on the mandatory analysis of such study programs by foreign universities were determine, indicate that the initiators form a package of project documents, which, among other things, includes a justification of the draft of the study program "which indicates the benefits of introducing a new study program, its features and differences from those in Ukraine and the world" [37] (p. 5). Experts evaluating the study program "Economics" of the third (educational and scientific level) implemented in this HEI noted that "The University policy on the development and renewal of SSPs 
(study and scientific program) stipulates that each of them is annually monitored and changed in accordance with global, European, and domestic trends in the specialty and industry, as evidenced by joint research, joint partnership agreements and joint SPs, and the implementation of a functional internationalization strategy" [38]. Regarding the research of Ukrainian study programs, the survey of the guarantors of the study programs shows an even higher percentage compared to the study of the experience of foreign universities (more than 90\%), noting that the main subjects of the research were educational components $(86.6 \%)$, program learning outcomes $(66.3 \%)$, and systems of organization highlighting the free choice of disciplines (47.9\%). This situation is also confirmed by the conclusions of the expert group on the above-mentioned study program "Economics", where the experts state that "studying the experience of similar domestic and foreign study programs, the SSP developers of the Vadym Hetman Kyiv National University of Economics, Simon Kuznets Kharkiv National University of Economics; partner universities of Eastern Europe: the D.A. Tsenov Academy of Economics (Svishtov, Bulgaria) and the Poznan University of Economics and Business (Poland), clearly indicate that the self-assessment data, which from this experience is rethought and applied ("compliance with modern approaches to the training of doctors of philosophy; the formation of the educational component content and the use of innovative teaching methods; combination for the innovative research and teaching component of the program; the social competencies to be acquired by a doctor of philosophy in economics, etc.)" [38].

Therefore, a prerequisite for the quality formation of the study program and its further continuous modernization is the study and use of experience of leading universities around the world-recognized authorities in the field, which would help to develop relevant approaches to education and training students to maintain international competitiveness in the contemporary labor market. However, in general, the self-assessment data from Ukrainian higher education institutions submitted for accreditation in 2019-2021 mostly indicate a very superficial study of this experience or even its complete absence, as the vast majority of information on self-assessment only names the experience of the university being studied and not identifying what components of study programs or educational activities under these programs were analyzed and used and for what purpose.

There is a similar situation with regard to the involvement of employers as the main external stakeholders in the formation of study programs, as the guarantors of study programs in the survey declare a high level of appeal to employers ( $89.9 \%$ of respondents). It is expected that the remarks of employers to the draft of the study program concerned practical training $(54.6 \%$ ) as a component of the SP (number of hours for internships, their content, indicative bases, etc.). The analysis of the documentation of the leading HEIs shows the normative basis for cooperation with employers and includes the professional practitioners, who are involved in classroom activities and organization, conducting internships, which are proposed during the formation of the study program, providing further "feedback", and the timely receipt of comments and suggestions for improving the practice-oriented component of the educational process. Most reputable freelancers have developed and approved the regulations on the so-called Employers' Councils. This document is designed to regulate the formation and functioning of expert councils of faculties/institutes/training centers employers in the relevant HEI. Among the tasks of such councils, the most important are processing suggestions and making recommendations while developing and/or changing study programs by taking into account current labor market trends and the needs of employers [39]; participation in the development of study programs in terms of defining the objectives of the program, program competencies, and program learning outcomes and improving the content of study programs and curricula [40]; and strengthening the role of employers (representatives of employers, employer organizations, their associations, etc.) in the professional training system-from the formation of the content of the study programs to the evaluation of learning outcomes [41]. At the same time, information on self-assessment and examination results (expert group reports) indicate a vague understanding of the role of employers in shaping the study program. In particular, an 
unreasonable choice of employer representatives for a specific study program and failure to take into account regional, sectoral, economic, and other criteria in attracting employers were common problems. Feedback and reviews were formal or too complementary, and they did not contain suggestions, comments, requirements. In many cases, their real impact on the formation of a quality study program was questionable.

Creating a quality study program is a long and multi-vector process, as the project team has the task of creating a competitive study program that meets the standards set in ESG 2015, and in particular, that takes into account the interests of all stakeholders and that correlates with the mission and strategy of a particular HEI. It is important that the study program meets the requirements of national legislation, sectoral and regional contexts, and other factors.

To achieve this compliance with the standard ESG 2015 p.1.2., each university must have clearly defined procedures for developing its own study programs; therefore, productive sources of the current state analysis of the study program formation process and participation of guarantors are the normative documents of higher education institutions, which, in turn, synthesize previous and current experiences.

It is noteworthy that the vast majority of scientists and practitioners who offer the phased design of the SP in their work mostly focus on the recommendations of the Tuning project [42] (p. 14) in the conclusion of the study program, which are quite complete and methodologically clear; however, they do not always correlate with the guidelines of the ESG, and in particular, more emphasis is placed on the formal component and less communication and cooperation with stakeholders is emphasized.

In order to clarify the model developed by us, the provisions of the study programs of twelve universities in Ukraine with different regional representation were analyzed according to the following parameters (Table 3):

(1) The stakeholder involvement mechanism;

(2) The study of the best practices;

(3) The determination of institutional capacity;

(4) The structure requirements;

(5) The discussion of the project;

(6) The monitoring of the proposals at all stages;

(7) The approval and coordination procedures.

Table 3. Comparative analysis of the regulations on SP [37,43-55].

\begin{tabular}{|c|c|c|c|c|c|c|c|}
\hline The Document Title, the Year of Approval & 1 & 2 & 3 & 4 & 5 & 6 & 7 \\
\hline 1. Regulations on study programs of the National Aviation University, 2020 & $\mathrm{~L}$ & $\mathrm{~L}$ & $\mathrm{H}$ & $\mathrm{H}$ & + & M & $\mathrm{H}$ \\
\hline 2. Regulations on study programs of the National University of Civil Defense of Ukraine, 2020 & $\mathrm{~L}$ & $\mathrm{~L}$ & $\mathrm{H}$ & S & + & M & S \\
\hline $\begin{array}{l}\text { 3. Regulations on study programs of the Volodymyr Vynnychenko Central Ukrainian State } \\
\text { Pedagogical University, } 2019\end{array}$ & M & M & $\mathrm{H}$ & $\mathrm{H}$ & - & M & S \\
\hline 4. Regulations on study programs of Volodymyr Dahl East Ukrainian National University, 2020 & M & $\mathrm{L}$ & M & $\mathrm{H}$ & + & $\mathrm{L}$ & $\mathrm{L}$ \\
\hline $\begin{array}{l}\text { 5. Regulations on study programs of the National University of Life and Environmental } \\
\text { Sciences of Ukraine, } 2018\end{array}$ & $\mathrm{~L}$ & $\mathrm{~L}$ & $\mathrm{~L}$ & $\mathrm{H}$ & - & $\mathrm{L}$ & $\mathrm{H}$ \\
\hline $\begin{array}{l}\text { 6. Regulations on the development and design of the study program at Zaporizhia National } \\
\text { University, } 2020\end{array}$ & M & $\mathrm{L}$ & $\mathrm{H}$ & $\mathrm{H}$ & + & $\mathrm{H}$ & $\mathrm{H}$ \\
\hline 7. Regulations on the study program of Vasyl Stus Donetsk National University, 2019 & $\mathrm{H}$ & $\mathrm{H}$ & $\mathrm{H}$ & $\mathrm{H}$ & + & $\mathrm{H}$ & $\mathrm{H}$ \\
\hline $\begin{array}{l}\text { 8. Regulations on the development and modernization of study programs of M.E. } \\
\text { Zhukovsky National Aerospace University, } 2019-2020\end{array}$ & $\mathrm{~L}$ & $\mathrm{~L}$ & $\mathrm{~L}$ & M & - & $\mathrm{L}$ & M \\
\hline 9. Regulations on study programs of Vasyl Stefanyk Precarpathian National University, 2019 & $\mathrm{M}$ & $\mathrm{L}$ & $\mathrm{L}$ & $\mathrm{H}$ & + & M & $\mathrm{H}$ \\
\hline $\begin{array}{l}\text { 10. Regulations on study programs and curricula of Drahomanov National Pedagogical } \\
\text { University, } 2020\end{array}$ & S & $\mathrm{L}$ & $\mathrm{L}$ & $\mathrm{H}$ & + & $\mathrm{S}$ & S \\
\hline 11. Regulations on study programs of I.I. Mechnikov Odessa National University, 2020 & S & $\mathrm{L}$ & $\mathrm{L}$ & $\mathrm{L}$ & + & S & S \\
\hline $\begin{array}{l}\text { 12. Regulations on the development and implementation of study programs of Yuriy } \\
\text { Fedkovych Chernivtsi National University, } 2019\end{array}$ & S & M & $\mathrm{L}$ & $\mathrm{H}$ & + & $S$ & $\mathrm{H}$ \\
\hline
\end{tabular}


Table 3: A four-step evaluation of these documents was applied at the following levels:

- High (H): the procedure is available, structured, and implemented at all stages to which it applies;

- Sufficient (S): the procedure is available, structured, and implemented sporadically;

- Medium (M): the procedure is available and partially structured;

- Low (L): the procedure is only mentioned in the document.

The analysis of the assessments shows that the parameters (structure requirements, adjustment and approval procedure) that focus on the formal components of the SP are implemented much better than those related to the strategic vision, long-term planning, and comprehensive cooperation with stakeholders (mechanism for involving stakeholders, studying best practices, monitoring proposals at all stages, in part determining institutional capacity).

In general, the positive dynamics of ensuring the local regulatory framework of HEIs in these years (2019-2020) is explained by the introduction of a new procedure for accreditation of an SP under the already mentioned regulation "On Accreditation of Educational Programs" (2019) [24], which is provided by almost all of the analyzed provisions of the HEI.

An analysis of the accreditation experience as an external evaluation of the quality of study programs in Ukraine and the best practices of Ukrainian universities allow us to offer a generalized model for forming a quality study program, which is aimed at practical use.

The first organizational stage after the decision to launch a study program should be the creation of a project team that performs the main organizational and analytical work and that coordinates and structures all of the available materials, in particular by forming the necessary package of documents.

The study program is a complex and multi-vector document, so the project team must offer an effective way to achieve the planned learning outcomes. In addition to regulations and recommendations in the field of higher education, it is essential to take into account ESG 2015 (requirements for the formation of the study program laid down in Standard 1.2 [3] (pp. 11-12), Development and approval of programs), standards of higher education in the specialty, professional standards, and internal policies of the university.

Necessary steps for the formation of a quality study program are:

1. Taking into account the interests of the main groups of stakeholders, especially potential employers and students.

The qualitative, rather than formal, involvement of interested representatives of these groups in the project group will help the project work better and will help avoid meaningful distortions, creating a more competitive study program.

According to ESG 2015, one of the principles of quality assurance in higher education in the European Higher Education Area is that "quality assurance takes into account the needs and expectations of students, all other stakeholders and society" [3] (p. 8). Thus, we state that cooperation with stakeholders is an important component of study program formation because it determines the validity of the opening of the SP, affects the formation of the project group, determines its focus, and lays the content of the future SP.

2 . The next step of the project group; in our opinion, the study programs of other study programs should be analyzed by taking into account not only domestic experience but also foreign experience. This is extremely important for the formation of study programs in Ukraine, as domestic programs have quite significant similarities, so while trying to create an original study program, one should carefully examine the experiences of other HEIs, bearing in mind the need to adapt the components of the SP to the current legislation.

As already mentioned, when studying the content of study programs, the vast majority of project groups only take into account the structure of the curriculum and the list of educational disciplines being studied. The involvement of experience is rather limited, and it is necessary to pay more attention to the content of educational components, methods of forming professional competences, and the combination of theory and practice when 
studying other components. Obviously, reproducing the list of educational components from a successful program does not guarantee the creation of a quality SP.

3. Information should be collected from stakeholders while other project groups are simultaneously researching other study programs. When working with groups of stakeholders, it should be taken into account that most members of these groups are not educators and cannot deeply understand the peculiarities of the educational process. Therefore, for high-quality cooperation with stakeholder groups, it is optimal to not only use queries with broad open questions to also conduct questionnaires with specific questions, such as possible types of practices, their content, or a list of additional competencies, etc. Qualitative sampling involves working with a sufficient number of and appropriate level stakeholders. The analysis the self-assessment information of higher education institutions from Ukraine submitted during the study program accreditation process revealed the involvement of representatives of small businesses or regional institutions as stakeholders, with the focus of the study program aimed at the national broad market. Thus, it is necessary to remember the need for cooperation both with representatives of small business and with representatives of large formal associations of this branch members. Stakeholder engagement segments are quite individual for different industries.

Surveying students from such study programs will help gather information for the formation of a study program that is not only useful but that is also convenient to consider study programs from the point of view of applicants. According to paragraph 1.3 of ESG15, it is recommended to assess /.../ the expectations, needs, and satisfaction of students regarding the program [3] (p. 16).

Members of the project team representing these categories of stakeholders should assist in structuring and adapting the materials obtained from the study program survey and their harmonious implementation. Foreign researchers confirm the importance of involving students in modern quality assurance processes, for example, Ella Kahu notes that "student engagement is a current buzzword in higher education, increasingly researched, theorized, and debated with growing evidence of its critical role in achievement and learning" [56].

4. Study programs, in accordance with standard 1.2 ESG, are developed on the basis of the general program objectives, which are consistent with the institutional strategy and have defined expected learning outcomes. Therefore, in cooperation with the administration of the educational institution, the project team should comprehensively assess the institutional capacity, starting with the correlation of the mission and strategy of the university and the goals of the SP; determine the relevance of the focus of the SP plan for the development of HEIs based on the study of the experience of the same or similar study programs; and assess the necessary material and human resources (in particular, financial, human, and other needs for the implementation of this study program). If the institutional capacity is potentially confirmed, the project team can conduct further steps.

5. The next step is to form a profile of the study program, its purpose, and to determine the program and additional competencies, program learning outcomes, and the content structure of the study program (list and sequence of study of educational components).

This task is possible by performing the actions mentioned in paragraphs $1-4$, which will gather the necessary material to form a quality profile of the study program. The specifics of the study program and curriculum profile must also meet the requirements of standard 1.2, which specifies that the study program is "designed so that they enable smooth student progression" [3] (p. 12). To implement this principle, it is advisable to use the matrix of correspondence as one of the important elements of the design work and the structural logical scheme. It is the matrices that allow us to show the relationship of general and professional competencies with the program learning outcomes as well as with the educational components that ensure their formation and achievement. The sequence and interdependence of educational components is laid down in the structural and logical scheme, with the study program and the curriculum as its component "define the expected student workload, e.g., in ECTS" [3] (p. 12). 
Other documents may be added to the package of documents at the discretion of the developers, in particular, on the study of the experience of other SPs, the wishes of stakeholders, materials of working groups, round tables, etc.

6. The next important step in the formation of a study program is to discuss its project. It is important to hold both internal discussions (within the university) and to involve representatives of the general academic community, employers, and students in the discussion of the draft study program. One of the obligatory events is the public announcement and invitation of stakeholders to discuss the draft study program [24]. The data from the broad discussion will help to identify possible errors and shortcomings of the project and will to help refine it.

7. Only after the analysis and consideration (or reasonable disregard) of the wishes and comments of the internal and external discussion, the study program (SP) can be suggested for formal approval in the manner prescribed by the university (HEI) in accordance with standard 1.2 ESG 2015, which states that study programs "are subject to a formal institutional approval process" [3] (p. 12).

\section{Discussion}

The complex process of Ukrainian higher education entering the European educational area is due not only due to the requirements of the time and the realities of the crisis in the quality of Ukrainian education at the beginning of the 21st century, but it is also due to rapid worldviews and economic changes in society, in particular, the inevitable awareness of the importance of quality practice-oriented education with mandatory consideration of the formation of soft skills as a component. Therefore, understanding and substantiating the curriculum design model in the context of ESG compliance has become an urgent need of modern Ukrainian higher education.

Systematizing scientific, methodical, and recommendatory works of Ukrainian researchers concerning the conclusion of study programs in terms of educational reforms and approximation to the requirements of the European educational area, the authors drew attention to the lack of research on certain parameters of the process of initiating and modeling study programs, which led both to a distortion of the understanding of the principles of concluding study programs and to an underestimation of accreditation as an external mechanism for ensuring the quality of study programs.

In 2019, before the introduction of the new accreditation procedure, researchers expressed doubts about the effectiveness of the accreditation procedure, stating that "Ukraine suffers from an underdeveloped culture of evaluation, provision and improvement of higher education" [7] (p. 178). Today the Ukrainian educational community is gradually changing this point of view in general, and the most progressive part of the community is already convinced of the need for accreditation as an assessment of the quality of study programs, and its representatives become "agents of change" to promote it. At the same time, the presence of progressive teachers in the HEI and the creation of a sectoral expert environment improves the quality of institutional processes related to the design of the SP.

Introduced in 2019, the regulation "On the accreditation of study programs", which provides training for higher education, has a regulatory status, implementing not only other approaches but also new categories, which cannot be said about most of the documents governing the quality of higher education when designing and approving a study program. At present, most of them do not perform a regulatory function but are advisory in nature. The regulation "On Accreditation" (2019) is based on the law "On Higher Education" (2014), which, according to S. Kvit, "breathed life into higher education" [6]. In fact, at that time, it was a very progressive document that set the guidelines for Ukrainian higher education to be integrated with European education, in terms of designing study programs in particular. The ESG 2015 guidelines correlate with the following patterns of implementation of new approaches to higher education in Ukraine, which were introduced as a result of the Law on Higher Education (2014), which emphasizes the protection of higher education seekers, accountability, orientation of the study program to ensure its quality, and the conclusion 
of programs, in the selection of educational components and ways to improve the SP in particular. At the time that ESG 2015 was adopted, Ukrainian scholars interpreted this system of approaches primarily as reconciling the positions of HEIs and independent agencies [5] (p. 10), which is a fair but partial understanding of this important document. First of all, it is positive in terms of the structure of the guidelines for the various stages of the SP and the specificity and balance of the terminology.

While working on this article, we used a number of terms that do not always have a fixed meaning and that can be interpreted differently depending on the context. Thus, we consider it necessary to set out and comment on the main terms mentioned and their meaning within the study.

Most of the terms and concepts in the article are defined in the interpretation of the Law of Ukraine "On Higher Education" [26], the Law of Ukraine "On Education" [57], and the Regulation "On Accreditation of Study Programs" [24]. However, some of these definitions need to be clarified, which will help to eliminate discrepancies and unjustified coincidences in the long term.

Study program accreditation, according to item 4. part 1 of Art. 1 of the Law of Ukraine "On Higher Education" is defined as the "evaluation of the study program and/or educational activities of higher education institutions under this program to ensure and improve the quality of higher education", which is currently implemented in practice through accreditation procedures [26].

The accreditation of study programs is a part of the system of external quality assurance of education, which may include tools, procedures, and measures to ensure and improve the quality of education.

The external quality assurance system cannot be implemented without the full functioning of internal quality assurance systems in higher education institutions, which constitute a balanced institutional mechanism that provides the interconnection of these components of educational quality.

As a phenomenon, a study program is a single set of educational components (disciplines, individual tasks, practices, tests, etc.) aimed at achieving the learning outcomes provided by such a program, which gives a student the right to obtain certain educational and professional (professional) qualifications) [26]. At the same time, in Art. 91 of the same law, a study program is defined as a document that must contain "a list of educational components; their logical sequence; requirements for the education level of people who can start training under this program; the number of ECTS credits required to complete the program, as well as the expected program learning outcomes (competencies) that the applicant has to master" [26]. That is, the homonymy of these terms is already laid down in the provisions of the Law on Higher Education. Despite these contradictions, within the limits of our article, we consider the study program more broadly than these documents, considering it to be a complex of stages, actions, activities, and components directed effecting the corresponding result. No less important for outlining the quality processes is the concept of a stakeholder, which is not regulated by Ukrainian educational legislation. However, we use this term to mainly mean the "stakeholder". Thus, in the research, we suggest using this term in such a sense.

Additionally, it is necessary to define and establish the concept of study program formation, and we suggest understanding it as the first stage of a continuous process of its creation by taking into account the regulatory requirements for its form and content and the planning of educational activities under the program that will provide constant internal and external monitoring of its quality.

We may consider the process to be divided into the phases of "starting an SP", "de-

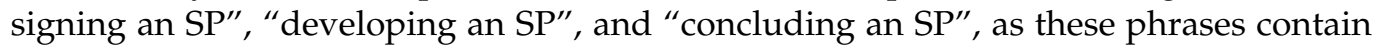
certain temporal or semantic accents; for example, "designing" will refer to more structural components. Concerning the decision to introduce an SP, such uncertainty is lacking in specific scientific and methodological developments, such as "Theoretical and methodological principles of study programs" (2016), which only detailed comments on the mandatory 
components of the $\mathrm{SP}$ - the result, although they declare a theoretical and methodological approach to the process [58].

The National Agency for Higher Education Quality Assurance approaches evaluating SPs according to qualitative rather than quantitative criteria after discussions and clarifications allow us to primarily focus on the parameters that are important for ensuring the quality of the SP, which are in line with the ESG guidelines. This is especially emphasized in the appendix to the Regulations on Accreditation of Study Programs, 2019-Criteria for evaluating study programs. It should be noted that the evaluation of the study program and educational activities of the study program is conducted according to each criterion and to the evaluation scale, which includes four levels of compliance: level " $\mathrm{F}$ "—-the study program and/or educational activities under this program do not meet certain criteria, and the identified deficiencies are fundamental and/or cannot be remedied within one year; level " $E$ " - the study program and/or educational activities under this program generally do not meet the defined criteria, but the identified shortcomings can be eliminated within one year; level " $\mathrm{B}$ " - the study program and educational activities under this program generally meet a certain criterion with shortcomings that are not significant; level " $\mathrm{A}$ " - the study program and educational activities under this program fully meet the defined criteria, including having an innovative/exemplary nature [24].

For example, criterion 1 "Design and goals of the study program" refers to the promotion of the SP, and the sub-criteria that make it up [24] are aimed at clarifying the processes and procedures of stakeholders, studying foreign and domestic experience, the clear inclusion of the SP in the development of the HEI, etc. During the implementation of accreditation procedures, which were conducted in the period from 1 September 2019 to 31 December 2020, out of 1400 SPs submitted for examination, only 75 (5.3\%) SPs demonstrated the exemplary level of assessment A according to this criterion. We note that these best practices confirm the effectiveness of the application of ESG recommendations in the formation of an SP. Thus, the National Pirogov Memorial Medical University (Vinnytsia) (SP "Pediatrics") confirms exemplary practices for studying Ukrainian and foreign experiences of similar SPs. Thus, the HEI states that "studying the recommendations of the EUA Council for Doctoral Education provided an opportunity to develop the individual educational trajectory of the applicant with the formation of self-control skills, which is realized in increasing the number of hours for self-work". The experience of Maastricht University provided an opportunity to introduce problem-oriented approaches for a number of academic disciplines. For instance, the "System of 7 steps", developed by the specialists of this university during the study of disciplines, "Publication activity and scientometric databases", "Academic integrity", etc., is actively implemented, which made it possible to strengthen the problem-oriented content of education [59].

However, such detailing of the actual monitoring of related SPs is rather isolated and is mostly not provided by the local regulatory framework of universities, which is shown by the analysis of the internal provisions of the Law on Study Programs. If we turn to Table 1, then indicator 2, The study of best practices, only one meets the regulations for HEI programs at a high level, two correspond to a medium level, and the rest correspond to a low level.

In fact, we see a problem in terms of the institutional polices of HEIs regarding the formation of a separate SP that is not sufficiently focused on attracting both internal and external stakeholders. Thus, in the methodological materials "Modern approaches to the construction of study programs" (2014) it is emphasized that "every teacher should know how learning outcomes are determined and how study programs will be formed" [10] (p. 3), but mechanisms for how to achieve this are not suggested; therefore, this important thesis remains only declarative.

It is not without reason that the Recommendations on the Application of Criteria for Evaluating the Quality of the Study Program of the National Agency, 2020, emphasize that "during the evaluation it should be taken into account that the circle of stakeholders will differ depending on the specifics of a particular program. It is important to find out the 
position of (potential) employers or the relevant professional community" [60]. Therefore, at each step of the formation of a separate SP, it is necessary to involve those groups of stakeholders whose participation will be most influential in this process.

The study "Stakeholders and Quality Assurance in Higher Education" rightly states that "students as stakeholders are supposed to be involved in evaluation of courses and to participate in internal quality assurance via decision-making and quality management processes at higher education institutions as equal partners. According to the ESG, the role of employers is more ambiguous. The ESG emphasizes the role of stakeholders in internal quality assurance in terms of representation as well as participation in study program development" [61] (pp. 3-4). Thus, despite the obvious interest of employers as a result of SP graduates-the university does not always realize the opportunity to involve employers to design a SP at the appropriate level. However, an HEI can mainly only attract a student after the introduction of educational activities under the SP. That is, we observe a collision when it is not so easy to determine the sequence and system of inclusion of stakeholders in the formation of the SP, even taking into account the guidelines of the ESG.

The reason why the study program formation model offered by the authors of the article resonates is debatable to some extent, especially concerning the harmonization model of the Tuning Project. The final brochure of this project offers a "model for the development, implementation and use of curricula, which allows to summarize the institutional parameters of determining the ability of HEI to start the SP" [42] (p. 14). It is significant that the questionnaire suggested in these materials is sufficiently detailed and is aimed at maximizing the involvement of stakeholders, in particular, to determine compliance with the basic conditions of a strategic nature: "Is the public need for this program identified at the regional/national/European level? Is this done in consultation with stakeholders: employers, professionals and professional organizations?" At the same time, institutional parameters are not overlooked; in particular, the study of the use of internal and external resources. All components of the SP are listed as a document, namely profile, goals, learning outcomes, general and professional competencies, curriculum and topics, and modules and credits according to specific educational elements, and approaches to teaching and learning as well as assessment. Of course, the project executors emphasize the need to develop an evaluation system designed to ensure continuous quality improvement [42] (pp. 14-15). However, this approach does not define the mechanism and stages of involving stakeholders or personal or collective responsibility for the study program at the stage of its formation.

In Ukrainian higher education, the role of the guarantor and the project team is important in the process of ensuring the quality of the study program and educational activities, in the formation of the study program in particular. This concept is repeatedly mentioned by Yu. Rashkevych, interpreting it as a person who is responsible for the SP [62] (p. 6). In European practices, such functionality is not observed; this is a Program Facilitator or Academic tutor in higher education, who monitors the actual implementation of the SP [63]. In Ukrainian conditions, such a person, as already mentioned in our article, is vital because the system of measures aimed at forming a quality study program and all necessary actions, procedures, and technology should be concentrated in the guarantor's focus as a knowledgeable moderator.

Quite optimal stages are offered by the regulations on study and scientific programs for the training of doctors of philosophy at the Ukrainian Medical Dental Academy UMDA at the first stage (stage 1), proposing the formation of a project team and the appointment of a guarantor for the study program. The following stages: stage 2-urgency analysis of a SSP and an estimation of sufficiency of available resources; stage 3-determination of the SSP profile; stage 4-determining the educational content of the SSP and developing a curriculum; stage 5-development of a system for assessing the quality of the SSP in order to improve it-are impossible without the organizational and effective involvement of the guarantor and the project team headed by them [64] (pp. 5-6). 
Introduced in 2019, the system of accreditation for study programs had a positive impact, particularly on the procedure of forming the study program, laying the groundwork for qualitative new approaches to the design of study programs, and the participation of all stakeholders. This system provided mandatory elements and stages of formation that were in accordance with the guidelines of the ESG, while leaving the choice of forms and ways to implement the process under the control of the HEI.

In general, one of the reasons why the greatest difficulties encountered when developing the concept of study program formation in the context of ESG is that some certain process parameters for initiating and modeling study programs by Ukrainian HEIs are still poorly studied. Another reason is the ambiguity of the term "study program" and the non-standardization of the key concepts "study program" and "stakeholder". As a result, Ukrainian HEIs have not yet developed a clear policy on the consistency and systematic involvement of stakeholders in the formation of study programs despite the available ESG guidelines.

Prospects for successful SP formation by Ukrainian institutions in the context of the ESG criteria are seen in the definition and legislative consolidation of the concepts "stakeholder" and "formation of a study program", the unification and the clear regulation of study program stages through legislative acts regulating activities in the field of education as well as in developing a strategy and sequence for involving stakeholders, determining personal and/or collective responsibility for the study program at the stage of its formation and incorporating such a policy in local regulations of higher education institutions.

Summarizing the practical impact of the suggested model, we can outline the prospects for its implementation. At the first stage of practical application, participation will be offered to the group of higher education institutions that have agreed to be the site of the experiment. During the approbation, there will be monitoring, and then the effectiveness of the model will be analyzed. In fact, the SP formation stages will be able to be unified and standardized to some extent through legislation.

\section{Conclusions}

An analysis of scientific and methodological achievements of Ukrainian and foreign authors showed that the problem of forming a study program attracts a large number of researchers, but their work mainly concerns individual aspects or generalizations of experience in study programs in certain fields or specialties.

Researchers provide recommendations for the application of general approaches for the development of study programs; sometimes, they trace the formal or some structural parameters of the SP, which must be followed during its formation. Herewith, there is an emphasis on the autonomy of higher education institutions, which allows, on the one hand, the discovery of unique SPs, and on the other hand, it blurs the clarity of the requirements for the formation of SPs.

At the same time, a review of the Ukrainian legal framework on the standardization of quality assurance in higher education shows that a number of key concepts regarding the conclusion of study programs need to be standardized and that the existing ones need to be improved. Such a problem has a negative impact on the development of local regulations of Ukrainian universities, which regulate the formation of SPs today.

After analyzing the existing conceptual framework for the quality assurance of educational activities, we found that it has certain gaps, so it was suggested that the concept of "formation of study program", the first stage of a continuous process of its conclusion, be defined by taking into account the regulatory requirements for its formation and content and the planning of educational activities under the program that will provide constant internal and external monitoring of its quality.

Our research, which is based on the developed samples of the SP and the local regulatory framework of universities, and the approaches suggested in theoretical work offer a comprehensive vision of the stages SP formation and depicts the architecture of this process. 
A model for the formation of study programs with clearly outlined stages has been developed in the current research and is correlated with ESG standards. In our opinion, the use of the suggested model is not only a theoretical development but can also serve as a flexible practical tool for the formation of a quality SP that follows the guidelines of ESG 2015 and national educational legislation.

This model is based on the analysis of positive and negative practices from the experience of the accreditation procedures of the National Agency for Quality Assurance in Higher Education of Ukraine (public); therefore, it is functional and based on theoretical generalizations of new approaches and real cases of Ukrainian HEIs.

The first stage of this process requires the involvement of a maximum variety of stakeholders, including employers; potential educators; internal stakeholders, including research and teaching staff; freelancers who will be involved in providing educational activities under the program, etc. (step 1).

At the same time, the experience of other similar or the same SPs should be studied (step 2). The research emphasizes the need for a comprehensive study of SPs and not just the structure of its educational components.

In the case of a positive decision, cooperation with stakeholders will become more applied, particularly in the form of surveys, round tables, "brainstorming", etc. (step 3).

Thus, it is important to broadly investigate the institutional capacity of an HEI to implement the SP: organizational, personnel, financial resources, and research potential (laboratories, equipment) (step 4). At this stage, there should also be active interaction with employers and students, and the SP should be self-governed by the HEI.

The collected information during the previous stages will allow the study program project to conclude (step 5), resulting in the formation of a study program, to the purpose of which is to define the program and additional competences and program results resulting from the training and semantic structure of the study program (list and sequence of studying of educational components).

During the discussion of the project (step 6), it is important to monitor all suggestions and to determine which of them will be considered or rejected and why as well as one to monitor the important components of the discussion that could be constructive for external and internal discussions to test decisions and make optimal proposals.

According to the ESG guidelines, the procedure for approving the study program (step 7) must be provided for and followed by the HEI, after which the SP can be implemented.

As such, the research conducted in our study provides practical steps to create a quality study program with maximum compliance with the guidelines of ESG 2015.

These steps are not rigid, and they can be changed or supplemented if necessary, but their usage is aimed at implementing the mandatory principles that will help during the work required for such projects. Thus, this development method can become both a practical tool and a basis for further research on methodological work and recommendations for the formation of study programs.

The application of this set of measures will help eliminate significant gaps in understanding the impact of the ESG guidelines on the formation of a quality study program in the realities of Ukrainian higher education, particularly in terms of structure, specific steps, and the role and place of stakeholders in the formation of a quality study program.

Author Contributions: Conceptualization, A.B., G.D. and O.Y.; methodology, G.D.; validation, A.B., G.D. and O.Y.; formal analysis, A.B., G.D. and O.Y.; investigation, A.B., G.D. and O.Y.; resources, A.B., G.D. and O.Y.; Data curation, G.D. and O.Y.; writing-original draft preparation, A.B., G.D. and O.Y.; writing-review and editing, O.Y.; supervision, O.Y.; project administration, A.B. All authors have read and agreed to the published version of the manuscript.

Funding: This research received no external funding.

Institutional Review Board Statement: Not applicable.

Informed Consent Statement: Informed consent was obtained from all subjects involved in the study. The survey is anonymous, so the participants agreed to provide their answers without specifying 
their identities, the answers are impersonal, and their personal data are not used; therefore, the survey did not need to be approved by the ethics committee.

Data Availability Statement: The data used in our study are publicly available on the website of the National Agency for Quality Assurance in Higher Education: the survey results of the study program guarantors [31] and in the database of accreditation cases [65] are in accordance with the policy of openness and transparency.

Conflicts of Interest: The authors declare no conflict of interest.

\section{References}

1. Ivancheva, M.; Syndicus, I. Higher education reform in the 'periphery'. Learn. Teach. 2019, 12, 1-16. [CrossRef]

2. Mbatha, N. Education 01? In Search of a New Operating System: Making Education More Relevant, Responsive and Authentic. Educ. Res. Soc. Chang. 2019, 8, 156-158.

3. ESG. Standards and Guidelines for Quality Assurance in the European Higher Education Area. Brussels, Belgium, 2015. Available online: http:/ /www.enqa.eu/wp-content/uploads/2015/11/ESG_2015.pdf (accessed on 11 September 2021).

4. Nesterenko, I. Study program design in the context of the functioning of the Polish qualification framework. Comp. Pedagog. Stud. 2013, 2-3, 16-17. (In Ukrainian)

5. Dobko, T.; Zolotarova, I.; Kalashnikova, S.; Kovtunets, V.; Kurbatov, S.; Lynova, I.; Luhovyi, V.; Prokhor, I.; Rashkevych, Y.; Sikorska, I.; et al. Development of the Quality Assurance System of Higher Education in Ukraine: Information-Analytical Review; Kalashnikova, S., Luhovyi, V., Eds.; Priorytety: Kyiv, Ukraine, 2015. (In Ukrainian)

6. Kvit, S. The Battlefront of Civilizations: Education in Ukraine; Kyiv-Mohyla Academy Publishing House: Kyiv, Ukraine, 2015.

7. Vorobiova, O.; Debych, M.; Luhovyi, V.; Orzhel, O.; Sliusarenko, O.; Talanova, Z.; Tryma, K. Analysis of the Leading Domestic and Foreign Experience in Assessing the Quality of Higher Education in the Context of European Integration: Analytical Materials (Part II); Luhovyi, V., Talanova, Z., Eds.; Institute of Higher Education NAPN: Kyiv, Ukraine, 2019. (In Ukrainian)

8. Rashkevych, Y.M. The Bologna Process and the New Paradigm of Higher Education; Lviv Polytechnic Publishing House: Lviv, Ukraine, 2014. (In Ukrainian)

9. Zakharchenko, V.M.; Luhovyi, V.I.; Rashkevych, Y.M.; Talanova, Z.V. The Development of Educational Programs. Guidelines; DP NVTS Priorytety: Kyiv, Ukraine, 2014. (In Ukrainian)

10. Kholin, Y. Modern Approaches to the Construction of Educational Programs. Metodological Materials. 2018. Available online: http:/ / www.univer.kharkov.ua/docs/work/curricula.pdf (accessed on 10 July 2021). (In Ukrainian)

11. Krektun, B.V.; Snitynskyi, V.V.; Rozhak, V.P. Application of innovative approaches to the creation of educational programs in the context of measures to reform the higher education system of Ukraine. Int. Sci. J. Prof. Appl. Didact. 2016, 2, 77-81. (In Ukrainian)

12. Krektun, B.V.; Snitynskyi, V.V.; Ishchenko, O.Y. Development of Educational Programs in the Sciences of the Environment in Accordance with the Provisions of ECTS: Educational and Methodical Manual; NU OMA: Odessa, Ukraine, 2017. (In Ukrainian)

13. Naboka, O. Educational program as a tool to ensure the quality of professional training of future professionals in higher education institutions. Coll. Sci. Sci. J. Natl. Pedagog. Univ. MP Drahomanov 2018, 60, 38-41. (In Ukrainian)

14. Ishchenko, O.Y. Basic approaches to the development of educational programs. Topical issues of linguistics, professional language didactics, psychology and pedagogy of higher education. In Proceedings of the V International Scientific-Practical Conference, Poltava, Ukraine, 19-20 November 2020; Astraya Publishing House: Poltava, Ukraine, 2020; pp. 167-172. (In Ukrainian)

15. Kvit, S. Higher Education in Ukraine in the Time of Independence: Between Brownian Motion and Revolutionary Reforms. Kyiv-Mohyla Humanit. J. 2020, 7, 141-159. [CrossRef]

16. Butenko, A.; Yeremenko, O. Preparation of the educational program for accreditation in the aspect of institutional interaction European values in Ukrainian education: Challenges and prospects. In Proceedings of the Collection of Materials of the International Scientific-Practical Conference, Zaporozhye, Ukraine, 28-29 May 2021; Tupakhina, O., Ed.; Helvetica Publishing House: Zaporozhye, Ukraine, 2021; pp. 28-31. (In Ukrainian)

17. Butenko, A.; Yeremenko, O. Legal status, professional and demographic portrait of the guarantor of the educational program. Yurydychnyi J. Pravo Ukr. 2021, 2, 171-185. (In Ukrainian)

18. Butenko, A.; Yeremenko, O. The role of the guarantor in the processes of quality assurance at the stage of formation of the educational program. Int. Sci. J. Univ. Leadersh. 2021, 11, 45-60. (In Ukrainian) [CrossRef]

19. Piskurska, H.V. Stakeholder Approach in Quality Assurance in Higher Education. Scientific Works of the Higher Educational “Donetsk National Technical University" Series. Pedagog. Psychol. Sociol. 2019, 69-77. (In Ukrainian)

20. Heikhman, Z. The role of employers in improving the quality of training of graduates of vocational higher education: A modern view. Quality management in education and industry: Experience, problems and prospects. In Proceedings of the Abstracts of the V International Scientific and Practical Conference, Lviv, Ukraine, 20-21 May 2021; LA Piramida: Lviv, Ukraine, 2021; pp. 32-34. (In Ukrainian)

21. Brenner, E.; Niehs, J. Curricula Development Based on Learning Outcomes-An Austrian Case. In Implementing Competence Orientation and Learning Outcomes in Higher Education_Processes and Practices in Five Countries; Cendon, E., Ed.; Project-Team HE_LeO, Danube Univ: Krems, Austria, 2008; pp. 59-81. 
22. Cronholm, S. Nine Principles for Designing a Study Program. Inf. Syst. Educ. J. 2006, 4, 31. Available online: http://urn.kb.se/ resolve? urn=urn:nbn:se:hb:diva-8246 (accessed on 15 July 2021).

23. Albir, A.H. Competence-based Curriculum Design for Training Translators. Interpret. Transl. Train. ITT 2007, 1-2, 163-195. [CrossRef]

24. National Agency for the Quality Assurance of Higher Education. About the Accreditation of Educational Programs in Higher Educational Institutions. 2019. Available online: https:// zakon.rada.gov.ua/laws/show/z0880-19\#Text (accessed on 15 July 2021). (In Ukrainian)

25. Artiukhov, A.; Butenko, A.; Wynnytskyi, M.; Denyskina, H.; Yevstifeiev, M.; Yeremenko, O.; Kvit, S.; Stukalo, N.; Kramarenko, K.; Kateryna, K.; et al. Annual Report of National Agency on Higher Education Quality Assurance from 2020 Year; Kvit, S., Yeremenko, O., Eds.; National Agency on Higher Education Quality Assurance: Kyiv, Ukraine, 2021. Available online: https://cutt.ly/Vzaxvnf (accessed on 12 August 2021). (In Ukrainian)

26. Law of Ukraine "On Higher Education" (Verkhovna Rada of Ukraine). Statements of Verkhovna Rada of Ukraine from 19 September 2014. Available online: https://zakon.rada.gov.ua/laws/show/1556-18\#Text (accessed on 12 August 2021). (In Ukrainian)

27. Ministry of Education and Science of Ukraine. Order of the Ministry of Education and Science of Ukraine Dated 1 February 2021 No. 128. On Approval of Requirements for Interdisciplinary Educational (Scientific) Programs. Available online: http: / / surl.li/adexi (accessed on 15 July 2021). (In Ukrainian)

28. Letter of the Ministry of Education and Science of Ukraine Dated 28 April 2017 No. 1/9-239 "Sample Educational Program (Recommendations of the Ministry of Education and Science of Ukraine). Available online: http://surl.li/adexo (accessed on 15 July 2021). (In Ukrainian)

29. Verkhovna Rada of Ukraine. Letter of the Ministry of Education and Science of Ukraine Dated 5 June 2018 No. 1/9-377. On Providing Explanations Regarding Educational Programs. Available online: https://zakon.rada.gov.ua/rada/show/v-377729-1 8\#Text (accessed on 15 July 2021). (In Ukrainian)

30. Ministry of Education and Science of Ukraine. Letter of the Ministry of Education and Science of Ukraine 1/9-434 from 9 July 2018. On Recommendations for Educational and Methodological Support. Available online: https://mon.gov.ua/ua/npa/listmon-19-434-vid-09072018-roku-shodo-rekomendacij-z-navchalno-metodichnogo-zabezpechennya (accessed on 15 July 2021). (In Ukrainian)

31. The National Agency for Higher Education Quality Assurance (NAQA). Summary of the Results of the Survey of Guarantors of Study Programs Programs. "Involvement of the Guarantor in the Formation of the Study Program". Available online: http:/ / surl.li/aieni (accessed on 2 July 2021). (In Ukrainian)

32. National Agency on Higher Education Quality Assurance. Report on the Results of the Accreditation Examination of the Educational Program No. 0033/AC-21. Available online: https://public.naqa.gov.ua/v1/form/2096?index=1 (accessed on 15 July 2021). (In Ukrainian)

33. Simon Kuznets Kharkiv National University of Economics. Regulations on the Procedure for Competitive Selection of Scientific and Pedagogical Employees of KhNEU. S. Kuznets and Concluding Employment Agreements (Contracts) with Them. Available online: https: / / bit.ly/3bH0A0u (accessed on 15 July 2021). (In Ukrainian)

34. National Agency on Higher Education Quality Assurance. Report on the Results of the Accreditation Examination of the Educational Program No. 0331/AC-21. Available online: https://public.naqa.gov.ua/v1/accreditation-folder/33461 (accessed on 15 July 2021). (In Ukrainian)

35. National Agency on Higher Education Quality Assurance. Report on the Results of the Accreditation Examination of the Educational Program No. 1046/ AC-20. Available online: http:/ / surl.li/adeyl (accessed on 5 September 2021). (In Ukrainian)

36. National Agency on Higher Education Quality Assurance. Glossary. Available online: http://surl.li/adeyq (accessed on 23 July 2021). (In Ukrainian)

37. Regulations on Educational Programs of the Vasyl' Stus Donetsk National University. 2019. Available online: https://phil.donnu. edu.ua/wp-content/uploads/sites/13/2020/09/polozhennya-pro-osvitnyu-programu_27.12.2019.pdf (accessed on 2 September 2021). (In Ukrainian)

38. National Agency on Higher Education Quality Assurance. Report on the Results of the Accreditation Examination of the Educational Program No. 1284(ПГ2)/AC-20. Available online: https://public.naqa.gov.ua/v1/accreditation-folder/3474 (accessed on 10 July 2021). (In Ukrainian)

39. Taras Shevchenko National University of Kyiv. Regulations on the Council of Employers at the Taras Shevchenko National University of Kyiv. Available online: http:/ / senate.univ.kiev.ua/?p=1466 (accessed on 10 July 2021). (In Ukrainian)

40. Sumy State University. Regulations on the Expert Councils of Employers of Sumy State University. Available online: http: / / surl.li/adffg (accessed on 10 July 2021). (In Ukrainian)

41. Borys Hrinchenko University of Kyiv. Regulations on the Council of Employers of Borys Hrinchenko University of Kyiv. Available online: https:// kubg.edu.ua/images/stories/Departaments/vdd/documenty/rozdil_10/nakaz_794_17.12.2020.pdf (accessed on 10 July 2021). (In Ukrainian)

42. González, J.; Wagenaar, R. Tuning Educational Structures in Europe, Universities' Contribution to the Bologna Process. An Introduction; University of Deusto Press: Bilbao, Spain, 2006. 
43. National Aviation University. Regulations on Educational Programs of the National Aviation University. 2020. Available online: http:/ / surl.li/aczsi (accessed on 10 July 2021). (In Ukrainian)

44. National University of Civil Defense of Ukraine. Regulations on Educational Programs of the National University of Civil Defense of Ukraine. Available online: http:/ / surl.li/kopb (accessed on 11 July 2021). (In Ukrainian)

45. Central Ukrainian State Pedagogical University Named after Volodymyr Vynnychenko. Regulations on Educational Programs at the Central Ukrainian State Pedagogical University Named after Volodymyr Vynnychenko. Available online: URL:http: / / surl.li/wluj (accessed on 10 July 2021). (In Ukrainian)

46. Volodymyr Dahl East Ukrainian National University. Regulations on Educational Programs of Volodymyr Dahl East Ukrainian National University. Available online: http:/ / surl.li/aczuo (accessed on 10 July 2021). (In Ukrainian)

47. National University of Life and Environmental Sciences of Ukraine. Regulations on Educational Programs at the National University of Life and Environmental Sciences of Ukraine. Available online: http:/ / surl.li/acztw (accessed on 10 July 2021). (In Ukrainian).

48. Zaporizhia National University. Regulations on the Development and Design of the Educational Program Zaporizhia National University. Available online: http:/ / surl.li/neiu (accessed on 10 July 2021). (In Ukrainian).

49. National Aerospace University. ME Zhukovsky. Regulations on the Development and Modernization of Educational Programs of the National Aerospace University. ME Zhukovsky. Available online: http://surl.li/ovhy (accessed on 10 July 2021). (In Ukrainian).

50. Vasyl Stefanyk Precarpathian National University. Regulations on Educational Programs at the Vasyl Stefanyk Precarpathian National University. Available online: http:/ / surl.li/aczti (accessed on 10 July 2021). (In Ukrainian)

51. National Pedagogical University Named after M.P Drahomanov. Regulations on Educational Programs and Curricula at the National Pedagogical University Named after M.P. Drahomanov. 2020. Available online: http://surl.li/gsgq (accessed on 10 July 2021). (In Ukrainian)

52. Odessa National University. II Mechnikov. Regulations on Educational Programs at Odessa National University. II Mechnikov. Available online: http:/ / surl.li/ydms (accessed on 10 July 2021). (In Ukrainian)

53. Yuri Fedkovych Chernivtsi National University. Regulations on the Development and Implementation of Educational Programs of Yuri Fedkovych Chernivtsi National University. Available online: http:/ / surl.li/aczvi (accessed on 10 July 2021). (In Ukrainian)

54. Semyon Kuznets Kharkiv National University of Economics. Organization of the Educational Process: Methodological Approaches to the Formation of a Variable Component of Educational Programs. Available online: https://www.hneu.edu.ua/wpcontent/uploads/2018/11/Tymchasove-polozhennya-pro-orhanizatsiyu-osvitnoho-protsesu-v-HNEU.pdf (accessed on 10 July 2021). (In Ukrainian)

55. Lviv National University Lviv Polytechnic. Regulations on the Formation, Approval and Updating of Educational Programs. 2017. Available online: https://lpnu.ua/polozhennia-pro-formuvannia-zatverdzhennia-ta-onovlennia-osvitnikh-program (accessed on 10 July 2021). (In Ukrainian)

56. Kahu, E.R. Framing student engagement in higher education. Stud. High. Educ. 2013, 38, 758-773. [CrossRef]

57. Verkhovna Rada of Ukraine. Law of Ukraine on Education. Vidomosti Verkhovnoi Rady 2017, 38-39, 380. Available online: https:/ / zakon.rada.gov.ua/laws/show/2145-19\#Text (accessed on 10 July 2021). (In Ukrainian)

58. Raskola, L.A.; Ruzhytska, O.M. Theoretical and Methodological Principles of Developing Educational Programs. Methodical Manual; Zaporozhchenko, O.V., Khmarskoho, V.M., Eds.; Odessa II Mechnikov National University: Odessa, Ukraine, 2016. (In Ukrainian)

59. National Agency on Higher Education Quality Assurance. Report on the Results of the Accreditation Examination of the Educational Program No. 1147/AC-21. Available online: https:/ / public.naqa.gov.ua/v1/accreditation-folder/4035 (accessed on 10 July 2021). (In Ukrainian)

60. Alkema, V.H.; Artiukhov, A.I.; Butenko, A.P.; Wynnytskyi, M.; Yevstyfeiev, M.I.; Yeremenko, O.V.; Zolotarova, I.O.; Kvit, S.M.; Medvediev, V.K.; Morklianyk, B.V.; et al. Recommendations for the Application of Criteria for Assessing the Quality of the Educational Program; Butenko, A.P., Yeremenko, O.V., Kvit, S.M., Eds.; Ukrainian Educational Publishing Center “Orion”: Kyiv, Ukraine, 2020. (In Ukrainian)

61. Leisyte, L.; Westerheijden, D.; Epping, E.; Faber, M.; de Weert, E. Stakeholders and Quality Assurance in Higher Education. In Proceedings of the 26th Annual Center for Higher Education Policy Studies Conference, Lausanne, Switzerland, 9-11 September 2013. Available online: https:/ / ris.utwente.nl/ws/portalfiles/portal/6152965 (accessed on 15 August 2021).

62. Rashkevych, Y. Guidelines for describing the educational program in the context of new standards of higher education. In Proceedings of the Guest Methodological Seminar of the Center for Educational and Innovative Technologies of the Ukrainian Catholic University, Lviv, Ukraine, 26 April 2017; Electronic Repository of the Ukrainian Catholic University. Available online: http:/ / er.ucu.edu.ua/handle/1/1105 (accessed on 15 August 2021). (In Ukrainian)

63. Jardim, J.; Bártolo, A.; Pinho, A. Towards a Global Entrepreneurial Culture: A Systematic Review of the Effectiveness of Entrepreneurship Education Programs. Educ. Sci. 2021, 11, 398. [CrossRef]

64. The Ukrainian Medical Dental Academy. Regulations on Educational and Scientific Training Programs for Doctors of Philosophy at the Ukrainian Medical Dental Academy. 2016. Available online: http:/ / surl.li/aczvm (accessed on 12 July 2021). (In Ukrainian)

65. National Agency on Higher Education Quality Assurance. Accreditation Cases. Available online: https://public.naqa.gov.ua (accessed on 12 July 2021). (In Ukrainian) 